\title{
Thirty Years after the Cuban Hemornhagic Dengue Epidemic of 1981
}

\author{
María G. Guzmán MD PhD DrSc
}

Translated from the Spanish and reprinted with permission from the Revista Cubana de Medicina Tropical, Vol 64, No 1, Jan-Apr 2012. Original available at: http://bvs.sld.cu/revistas/mtr/vol64_1_12/mtr01112.htm

\begin{abstract}
In 1981, Cuba reported the first hemorrhagic dengue epidemic in the Americas, with 344,203 cases, including 10,312 severe and very severe cases, resulting in 158 deaths. In the 30 years following the epidemic, surveillance, control and research have kept Cuba dengue free; although isolated, interrupted epidemics and transmissions have been reported. In this article, we summarize issues of interest regarding the 1981 epidemic, as well as laboratory surveillance data and various related research results.
\end{abstract}

KEYWORDS dengue, hemorrhagic dengue, Cuba, 1981 epidemic

\section{INTRODUCTION}

Dengue in the Americas and Cuba before 1981 Dengue is an acute febrile disease caused by any of four dengue virus serotypes (Den 1, 2, 3, 4) transmitted to humans by the Aedes aegypti mosquito. It has been recognized in the Americas since the 18th century, although epidemics of a dengue-type disease were reported as early as 1699 in Panama. In 1780, dengue was first described during an epidemic in Philadelphia. Information for the period between 1780 and 1800 is scarce. During the 19th century and first half of the 20th century, publications refer to epidemics occurring mainly in the Caribbean and southern United States.[1,2]

In the early 1950s, dengue virus (Den 2) was isolated for the first time in the Americas, in nonepidemic conditions in Trinidad and Tobago. From 1960 to 1980 , the region experienced three large epidemics: Den 3 in 1963-1964, Den 2 and Den 3 in 1968-1969 and Den 1 in 1977-1978. These epidemics, characterized by the benign form of the disease (dengue fever, DF) mainly affected countries in the Caribbean, Central America and some countries in South America.[2,3] This was a period of low endemicity with isolated cases of dengue hemorrhagic fever (DHF), the severe form of the disease.[1]

After 1945, the year Havana experienced a dengue outbreak, there were no cases of suspected dengue reported until introduction of Den 1 virus during the 1977 pandemic.[4,5] Serologic studies during the early 1970 s confirmed absence of circulating dengue virus in Cuba at the time.[6] During the Den 1 epidemic in 1977 , more than 400,000 cases were reported, all of the benign form.[5,7] Later serologic studies demonstrated that $44.46 \%$ of the Cuban population was infected by this virus serotype and at risk of secondary infection if another dengue virus serotype were to enter the country.[6]

\section{THE 1981 CUBAN HEMORRHAGIC DENGUE EPIDEMIC}

Background At the end of 1980, there was low circulation of Den 2 virus in the Americas region. On the other hand, almost half the Cuban population was at risk of a second infection by another dengue serotype. Finally, at the beginning of 1981 the first intro- duction of Den 4 virus in the region was reported (in Dominica), as well as the first epidemic of DHF, the latter in Cuba.[1,3,8]

Data on the epidemic The epidemic was recognized as such in late May 1981. Retrospective epidemiologic studies found it had begun at the end of 1980 in three municipalities located in eastern, central and western Cuba. Cases were reported during the same epidemiologic week in persons with no history of travel outside the country or their localities. A total of 344,203 cases were registered, including 10,312 severe and very severe cases, resulting in 158 deaths (101 of them children) (Table 1).

Table 1: General data on the Cuban hemorrhagic dengue epidemic of 1981

\begin{tabular}{|l|l|}
\hline Detection & Late May 1981 \\
\hline Etiologic agent & Den 2 virus, Asian genotype \\
\hline Total cases reported & $\begin{array}{l}344,203, \text { with } 10,312 \text { serious } \\
\text { (9203 severe and } 1109 \text { very } \\
\text { severe) and 158 deaths }\end{array}$ \\
\hline Case fatality & $0.49 / 1000$ patients \\
\hline Mortality & $1.58 / 100,000$ population \\
\hline Duration & Four months \\
\hline Date last case reported & October 10,1981 \\
\hline Months with most case reports & June, July, August \\
\hline Date with most case reports & July $6(11,400$ cases) \\
\hline Hospitalizations over four months & 116,151 \\
\hline
\end{tabular}

Clinical presentation DHF was seen both in children and adults.[8,9] In the former, clinical presentation was similar to that reported in Southeast Asia.[9-11] In adults, this was the first report of an epidemic of this nature.[12] Shock was more frequent in children but more severe in adults. Serologic studies showed that DHF was seen in cases of Den 1/Den 2 secondary infection, with a frequency of 1 in every 23 secondary infections in children and 1 in every 79 in adults.[13] Studies of these cases permitted identification of DHF clinical warning signs for the first time.[9]

Management, control and elimination of the epidemic This process included establishment of clinical guidelines for diagnosis and case management, in which early hospitalization and appropriate hydration were crucial for adequate recovery. For better patient care and surveillance, schools were converted into hospitals, with a network for immediate transport of patients requiring hospitalization. Medical personnel were also redistributed according to patient needs and expert groups were created to rapidly train both medical and paramedical personnel. Medical students played an essential role in clinical surveillance of hospitalized patients, carrying out followup of clinical findings and monitoring for DHF warning signs.

An intensive vector eradication campaign was mounted, in which community participation was fundamental.[7,14] The measures 
taken made it possible to end the epidemic in four months, the last case reported on October 10, 1981.

Etiologic agent diagnosis and laboratory surveillance Studies of sera collected during the first days of fever onset in patients with clinically suspected dengue enabled detection of elevated levels of flavivirus antibodies. These results, together with clinical signs and symptoms typical of the disease and population epidemiologic status, led to a presumptive dengue diagnosis and communication to health authorities that a DHF epidemic was under way. Viral isolation studies from samples collected during the acute disease phase enabled isolation and identification of Den 2 as the etiologic agent in the earliest days of the epidemic.[15-17]

For better followup and characterization of the epidemic, serologic surveillance was established in three stages:

1. The first, until July 24 , was aimed at identifying the epidemic's etiologic agent and confirming transmission throughout the country's provinces. During this stage, 4000 single serum samples from patients were processed.

2. During the second stage, clinical cases were confirmed by studying paired sera to determine diagnostic efficacy. In this stage, 2017 paired sera were studied.

3. In the third and final stage, $100 \%$ of suspected dengue cases were studied in order to certify elimination of the epidemic. During the entire epidemic period, virologic surveillance was maintained, allowing virus isolation in samples from 22 cases of DF and DHF, some of the latter fatal.[15,17]

Research during the epidemic The first studies carried out during and after the epidemic's elimination enabled: a) characterization of DHF clinical presentation in both children and adults with confirmed Den 2 infection; b) clinical, virologic and pathologic characterization of manifestations in 13 children who died of DHF; c) identification of DHF risk factors in several groups of patients with confirmed infection; d) characterization of the etiologic agent; e) establishment of primary and secondary infection serologic criteria in the Cuban setting; and f) introduction of new diagnostic technology.[9-12,15-23]

\section{2- 2011 PERIOD}

In the 30 years since the 1981 DHF epidemic, increases in dengue and DHF have been observed worldwide, with increases in cases and epidemics reported, as well as geographical extension of vector and dengue transmission. Today, an estimated one third of the world population lives in areas at risk for infection. The disease is reported in Southeast Asia, the Western Pacific, the Americas, Africa and the Eastern Mediterranean. All four viral serotypes have been identified in each of these regions. [24,25]

In the Americas, reports of dengue have increased sixfold, and of DHF 12-fold. In 2010, 1,663,276 cases were reported; 48,954 were DHF and there were 1194 deaths. Thirty countries report co-circulation of two or more serotypes. Epidemics have become more frequent and the cycles between them shorter (See http:// new.paho.org/hq/index.php?option=com_content\&task=view\&id $=4497 \&$ Itemid $=3526 \&$ limit=1\&limitstart=3). $[26]$ ).

In this complex context, Cuba has worked throughout these years to keep the country transmission-free. These efforts rely on a strong laboratory-supported clinical epidemiologic surveillance program that, together with the vector control and eradication program, has kept dengue from becoming endemic, even within a very complex regional context. Decisive to this achievement are political will, community participation and intersectoral action.

Diagnosis and surveillance Over the last 30 years, apart from strengthening diagnostic, surveillance and reference activities, dengue studies have been carried out in different disciplines. They have supported the country's surveillance and control programs and have also provided new evidence and insights for Cuba and the world. Cuba is acknowledged today as the only country to succeed in remaining free from endemic dengue, eliminating transmissions when these have occurred. It is also considered a center of excellence for training personnel and, through international collaboration and reference activities, has assisted many countries in the region in their efforts to confront and control dengue.

The country is working on improving comprehensive surveillance (environmental, entomologic, epidemiologic, clinical and laboratory) with participation by all levels of the health system. Laboratory surveillance is mainly aimed at early identification and confirmation of transmission, followup and characterization of epidemics and their etiologic agent, and at certification of transmission elimination. In 1997, active surveillance was established to search for cases and confirm diagnosis. Critical to this pursuit have been: the primary health care subsystem; the network of provincial laboratories capable of serologic diagnosis with Cuban technology (UMELISA Dengue IgM developed by the Immunoassay Center); national reference center activities (responsibility of the Pedro Kouri Tropical Medicine Institute's National Reference Laboratories); and active integration of all levels of the system to ensure dynamic analysis of epidemiologic situations.

Within this comprehensive strategy, vector surveillance plays a decisive role, in order to identify increases in vector presence and breeding grounds, enabling prompt action to decrease risk and in order to measure insecticide resistance. These activities rely on a network of entomology laboratories throughout the country, as well as the Pedro Kourí Tropical Medicine Institute's National Entomology Reference Laboratory and the National Vector Surveillance and Control Division.

Clinical epidemiologic surveillance at all levels of the national health system is another essential part of the comprehensive strategy, enabling early risk identification, timely notification of cases and study of their temporal-spatial distribution, as well as design and evaluation of elimination strategies. These actions are inserted in the Cuban program for international sanitary control.

\section{RESULTS OF VARIOUS STUDIES CARRIED OUT DURING THE PERIOD}

Unlike the experience in Southeast Asia and most countries of the Americas, epidemics in Cuba have been eliminated when they have occurred. Subsequent to the 1981 epidemic, others have been reported: one in 1997 (Den 2) in Santiago de Cuba and one in 2001-2002 (Den 3), mainly affecting the capital city.[27-31] After 2004, transmissions of imported cases have been reported, which have been controlled and eliminated. In 2006, another epidemic was reported, which was also eliminated (http://www.paho .org/spanish/ad/dpc/cd/eid-eer-2006-oct-24.htm). In this epidemiologic context, research has provided new knowledge in the field of dengue. Several of the main results are summarized below: 
1. Virologic, immunologic and clinical epidemiologic studies have enabled characterization of the 1981, 1997 and 20012002 epidemics, providing important data for early diagnosis and followup of outbreaks and understanding of decisive factors in their control and elimination, as well as contributing better knowledge of dengue.

2. Secondary infection by a different serotype than the primary infection has been confirmed as the main risk factor for DHF. Greater risk for DHF has been associated with certain viral sequences (Den 1/Den 2; Den 1/Den 3), and more production of IL-10 has been observed in these patients. Research showed higher DHF rates with secondary infection in children than in adults, and identified DHF cases during tertiary infections. Finally, seroepidemiologic studies have made it possible to determine dengue and DHF case rates according to type of infection and serotype in the Cuban setting. [13,20,30-35]

3. For the first time, it was demonstrated that higher DHF risk was associated with longer interval between infections. It was also shown that humoral response specificity increased with time, with decreasing heterologous neutralizing antibodies and memory T-cell cross-reactivity persisting even 20 years after primary infection.[36-38]

4. DHF risk factors identified were: white skin color, bronchial asthma, diabetes mellitus and sickle cell disease.[20,23]

5. Higher association with DHF was found for persons of European descent, with stronger memory T-cell response and cross-reactivity in white compared with black dengueimmune persons and with higher IFN alpha production in white persons.[39-43]

6. Increased and different expression levels of chemokines and cytokines (CCL2, CCL3, TNFa, IFNy, IL-10 and TGF $\beta$ ) were demonstrated in persons with different dengue immunity histories, suggesting that previous immunity to a serotype strongly influences early immune response to reinfection. $[34,35,44]$

7. Immune response genes associated with disease severity (HLA class I A*31, B*15, Fc g Rlla HH131, MICA*008 and MICB ${ }^{\star} 008$ ) or protection (HLA class II DRB1*04, DRB1*07, Fc g RIla RR31) have been identified.[41,45]

8. Virus role in severity of Cuban epidemics was demonstrated, with identification of strains and genotypes capable of producing DHF. An evolving pattern was demonstrated in nonstructural proteins in strains isolated at different points in the epidemic.[46-52]

9. Increase in epidemic severity was associated with longer duration, with possible selection of more virulent virus variants, whether by neutralization escape (hypothesis of escape mutants) or viral evolution.[20,23,49,53]

10. A comprehensive hypothesis was put forward, explaining the development of DHF epidemics, in which host and virus characteristics and epidemiologic conditions play a fundamental role.[8,23,54]

11. Research aimed at better clinical understanding of the disease has enabled its characterization, greater comprehension of its complications, detection and validation of clinical warning signs and demonstration of dengue infection clinical sequelae even a year after infection, as well as its possible relation to an autoimmune phenomenon.[9,21,55-61]

12. Studies to develop and implement diagnostic methods, characterize humoral immune response in patients with primary or secondary infection, and to determine diagnostic useful- ness of different clinical specimens have been important in laboratory surveillance (serologic, virologic and molecular) and in deepening understanding of the disease.[62-73]

13. Production of biologic reagents such as monoclonal antibodies, diagnostic kits for dengue IgM antibody determination by an ultramicroanalytic system (SUMA), among others, has contributed to serologic diagnosis and better understanding of this agent.[74-76]

14. It has been shown that efforts to control Aedes aegypti are only sustainable through conscious, systematic, proactive and preventive actions carried out by persons and groupswhat in the Cuban context we term "autofocal," referring to a "set of measures directed towards detection and elimination of possible mosquito breeding places. It hinges on weekly self-directed inspection by families and workers in their homes and workplaces."

15. During this period, research has been carried out to improve comprehensive, integrated surveillance, institutionalizing community strategies against dengue and evaluating community interventions, as well studying new control methods.[77-82]

16. Among the main studies undertaken are those aimed at estimating key epidemiologic parameters during outbreaks and seasonality of Ae. aegypti and Ae. albopictus populations; determining the entomologic burden for dengue transmission; developing methods to predict dengue severity; designing models to analyze social conditions favoring transmission and of models for measuring Ae. aegypti infestation. [78,79,83-89]

17. Research on dengue's economic impact has identified costs during and outside of transmission periods; costs of prevention programs, clinical case control and direct and indirect costs to families; cost-effectiveness of community participation strategies; and cost-effectiveness of vector control measures for Ae. aegypti.[90-93]

18. Development of a Cuban vaccine candidate for dengue control is one of the principal lines of research in the country. In this context, a model for obtaining attenuated vaccines was designed; humoral and cellular immune responses induced by membrane proteins and their precursor were characterized; a monkey model was established for dengue vaccine candidate evaluation; and the immunogenic and protective capacity of Den 4 virus envelope protein expressed in Pichia pastoris was assessed. Currently, two vaccine candidates based on a recombinant strategy (domain III of the dengue virus envelope protein and capsid/domain III) have shown satisfactory results in preclinical studies.[74,94-121]

\section{INTERNATIONAL COLLABORATION}

During the past 30 years, the country has maintained strong collaboration with countries in our own and other geographic regions, as well as with international organizations involved in dengue study (PAHO; WHO; Special Programme for Research and Training in Tropical Diseases, TDR; Dengue Vaccine Initiative, DVI; and others). Several approaches enable Cuba to share its knowledge and capacities for better dengue control with other nations, and also to keep current on the global situation, benefiting from dengue control strategies and research by other countries and international organizations. These approaches are: participation in diagnosis, clinical management of patients and outbreak response and control; evaluation of control programs in countries of the Americas; coordination of quality control tests; introduction of diagnostic methodologies; evaluation of insec- 
ticide resistance; personnel training in several dengue-related disciplines; introduction and evaluation of the new dengue clinical classification; implementation in the region of the Integrated Management Strategy for Dengue Prevention and Control (IMS) promoted by PAHO; participation in international expert groups (PAHO, WHO, TDR, DVI, among others); participation in multicenter research projects; and collaboration with high-level national and international scientific institutions.

\section{CONCLUSIONS}

During these 30 years, unlike most countries of the region, Cuba has been able to keep dengue from becoming endemic. Epidemics and transmissions that have occurred have been interrupted. The country has followed the five basic principles recommended by WHO-PAHO for dengue response, political will being the fundamental pillar and promoter of success. Nevertheless, the increasing complexity of dengue's epidemiologic situation in the region and the high and growing volume of travel between Cuba and endemic regions enhance risk. In this context, the country is working to strengthen and improve its programs. Application of scientific results and continuous and increasing international collaboration must play a key role in a more effective response to dengue.

\section{DEDICATION}

This paper is dedicated to the memory of Professor Gustavo Kourí Flores, who through his work, dedication and teaching was a tireless warrior in the battle against dengue. He worked intensively to develop Cuban science, as a fundamental contribution to addressing infectious and tropical diseases.

\section{ACKNOWLEDGMENTS}

The author wishes to thank all those who work day after day in the different fields, disciplines and jurisdictions of the country to keep dengue at bay, as well as the Cuban people, without whom the successes to date would not be possible.

Thanks also to Drs Gisel García, Maritza Pupo and Ángel Álvarez of the Pedro Kourí Tropical Medicine Institute for useful comments and suggestions in revision of the manuscript. -1 .

\section{REFERENCES}

1. Gubler DJ, Kuno J. Dengue and dengue hemorrhagic fever: CAB International 198 Madison Avenue: New York, NY 10016-4341 USA; 1997.

2. Guzmán MG, Kourí G. Dengue and dengue hemorrhagic fever in the Americas: lessons and challenges. J Clin Virol. 2003 May;27(1):1-13.

3. PAHO. Dengue and Dengue Hemorrhagic Fever in the Americas. Pan American Health Organization Guidelines for Prevention and Control: Scientific Publication; 1994. p. 548.

4. Hoffman WH. La endemicidad pandémica de dengue en los países cálidos. Rev Med Trop Parasit. 1943;9:11-8.

5. Mas P. Dengue fever in Cuba in 1977. PAHO 1978;375:40-3.

6. Cantelar de Francisco N, Fernández A, Albert Molina L, Pérez Balbis E. Circulación de dengue en Cuba. 1978-1979. Rev Cubana Med Trop. 1981;33(1):72-8.

7. Terry H, Figueredo R, Martínez S, Armando $\mathrm{J}$, Trigo J, Antuna $\mathrm{T}$, et al. Preliminary report on the national extermination campaign of Aedes (S) aegypti in the Republic of Cuba (31 May 1981 to 20 March 1982). Z Gesamte Hyg. 1984;30(12):737-8.

8. Kourí GP, Guzmán MG, Bravo JR, Triana C Dengue haemorrhagic fever/dengue shock syndrome: lessons from the Cuban epidemic, 1981. Bull World Health Organ. 1989;67(4):375-80.

9. Martínez-Torres E. Dengue and hemorrhagic dengue: the clinical aspects. Salud Publica Mex. 1995;37(Suppl):S29-44

10. Guzmán MG, Kourí G, Morier L, Soler M, Fernández A. A study of fatal hemorrhagic dengue cases in Cuba, 1981. Bull Pan Am Health Organ. 1984;18(3):213-20.

11. Guzmán MG, Kourí G, Martínez E, Bravo J, Riverón R, Soler M, et al. Clinical and serologic study of Cuban children with dengue hemorrhagic fever/dengue shock syndrome (DHF/DSS). Bull Pan Am Health Organ. 1987;21(3):270-9.

12. Díaz A, Kourí G, Guzmán MG, Lobaina L, Bravo $J$, Ruiz A, et al. Description of the clinical picture of dengue hemorrhagic fever/dengue shock syndrome (DHF/DSS) in adults. Bull Pan Am Health Organ. 1988;22(2):133-44.

13. Guzmán MG, Kourí GP, Bravo J, Soler M, Vázquez S, Morier L. Dengue hemorrhagic fever in Cuba, 1981: a retrospective seroepidemiologic study. Am J Trop Med Hyg 1990;42(2):179-84.

14. Armada Gessa JA, Figueredo González R. Application of environmental management principles in the program for eradication of Aedes (Stegomyia) aegypti (Linneus, 1762) in the Republic of Cuba, 1984. Bull Pan Am Health Organ. 1986;20(2):186-93.

15. Kourí Flores G, Guzmán Tirado MG, Bravo González J, Calunga Ríos M. Actividades del laboratorio de arbovirología durante la epidemia de dengue hemorrágico en Cuba, 1981. Rev Cubana Med Trop. 1982;34(2):107-13.

16. Kourí G, Mas P, Guzmán MG, Soler M, Goyenechea A, Morier L. Dengue hemorrhagic fever in Cuba, 1981: rapid diagnosis of the etiologic agent. Bull Pan Am Health Organ. 1983;17(2):126-32.

17. Guzmán Tirado MG, Kourí Flores G, Soler Nodarse M, Morier Díaz L, Vázquez Ramudo $\mathrm{S}$. Aislamiento del virus del dengue 2 en sueros de pacientes utilizando el ratón lactante y cultivo de células LLCMK2. Rev Cubana Med Trop. 1984;36(1):4-10.

18. Guzmán MG, Kourí GP, Bravo J, Calunga M Soler M, Vázquez S, et al. Dengue haemorrhagic fever in Cuba. I. Serological confirmation of clinical diagnosis. Trans R Soc Trop Med Hyg. 1984;78(2):235-8

19. Guzmán MG, Kourí GP, Bravo J, Soler M Vázquez $S$, Santos $M$, et al. Dengue haemorrhagic fever in Cuba. II. Clinical investigations. Trans R Soc Trop Med Hyg. 1984;78(2):239-41.

20. Bravo JR, Guzmán MG, Kourí GP. Why dengue haemorrhagic fever in Cuba? 1. Individual risk factors for dengue haemorrhagic fever/dengue shock syndrome (DHF/DSS). Trans R Soc Trop Med Hyg. 1987;81(5):816-20.

21. Martínez E, Guzmán MG, Valdés $M$, Soler $M$, Kourí G. Fiebre del dengue y dengue hemorrágico en infantes con infección primaria. Rev Cubana Med Trop. 1993:45(2):97-101.

22. Kourí G, Guzmán MG, Bravo JR. Criterios utilizados durante la epidemia de dengue hemorrágico para definir los casos positivos y las respuestas primarias y secundarias en la prueba de inhibición de la hemaglutinación, Cuba 1981. Rev Cubana Med Trop. 1983;35(1):4-10.
23. Kourí GP, Guzmán MG, Bravo JR. Why dengue haemorrhagic fever in Cuba? 2. An integral analysis. Trans R Soc Trop Med Hyg. 1987;81(5):821-3.

24. Guzmán MG, Halstead SB, Artsob H, Buchy P, Farrar J, Gubler DJ, Hunsperger E, et al. Dengue: a continuing global threat. Nature Rew Microbiol. 2010: S7-16.

25. WHO. Dengue. Guidelines for diagnosis, treatment, prevention and control. Geneva: World Health Organization; 2009.

26. San Martín JL, Brathwaite O, Zambrano B, Solorzano JO, Bouckenooghe A, Dayan $\mathrm{GH}$, et al. The epidemiology of dengue in the americas over the last three decades: a worrisome reality. Am J Trop Med Hyg. 2010;82(1):128-35

27. Kourí G, Guzmán MG, Valdés L, Carbonel I, del Rosario D, Vázquez S, et al. Reemergence of dengue in Cuba: a 1997 epidemic in Santiago de Cuba. Emerg Infect Dis. 1998;4(1):89-92.

28. Pelaez O, Guzmán MG, Kourí G, Pérez R, Martín JLS, Vázquez S, et al. Dengue 3 epidemic in Havana, 2001. Emerg Infect Dis. 2004;10(4):219-22.

29. Valdés L, Guzmán MG, Kourí G, Delgado J, Carbonell I, Cabrera MV, et al. Epidemiology of dengue and hemorrhagic dengue in Santiago, Cuba 1997. Rev Panam Salud Publica. 1999;6(1):16-25.

30. Guzmán MG, Kourí G, Valdés L, Bravo J, Álvarez M, Vázquez $S$, et al. Epidemiologic studies on Dengue in Santiago de Cuba, 1997. Am J Epidemiol. 2000;152(9):793-9.

31. Guzmán MG, Álvarez A, Vázquez S, Álvarez M, Rosario D, Pelaez O, et al. Epidemiologic studies on dengue 3 in Playa municipality, Havana, Cuba, 2001-2002. Int J Inf Dis. 2011.

32. Álvarez M, Rodríguez-Roche $\mathrm{R}$, Bernardo $\mathrm{L}$, Vázquez S, Morier L, González D, et al. Dengue Hemorrhagic Fever Caused by Sequential Dengue 1-3 Virus Infections over a Long Time Interval: Havana Epidemic, 2001-2002. Am J Trop Med Hyg. 2006;75(6):1113-7.

33. Álvarez MPA, Vázquez S, Morier L, Álvarez AM, Guzmán MG. Secuencias de infección viral asociadas a la fiebre del dengue durante la epidemia de dengue 3 de ciudad de La Habana, 20012002. Rev Cubana Med Trop. 2008;60(1):26-30.

34. Pérez AB, Sierra B, García G, Aguirre E, Babel $\mathrm{N}$, Álvarez M, et al. Tumor necrosis factor-alpha, 
transforming growth factor-beta1, and interleukin-10 gene polymorphisms: implication in protection or susceptibility to dengue hemorrhagic fever. Hum Immunol. 2010;71(11):1135-40.

35. Pérez AB, García $G$, Sierra B, Álvarez $M$, Vázquez S, Cabrera MV, et al. IL-10 levels in Dengue patients: some findings from the exceptional epidemiological conditions in Cuba. J Med Virol. 2004;73(2):230-4.

36. Guzmán MG, Kourí G, Valdés L, Bravo J, Vázquez S, Halstead SB. Enhanced severity of secondary dengue-2 infections: death rates in 1981 and 1997 Cuban outbreaks. Rev Panam Salud Publica. 2002;11(4):223-7.

37. Guzmán MG, Álvarez M, Rodríguez-Roche R, Bernardo L, Montes T, Vázquez S, et al. Neutralizing antibodies after infection with dengue 1 virus. Emerg Infect Dis. 2007;13(2):282-6.

38. Sierra B, García G, Pérez AB, Morier L, Rodríguez $\mathrm{R}$, Álvarez $\mathrm{M}$, et al. Long-term memory cellular immune response to dengue virus after a natural primary infection. Int $\mathrm{J}$ Infect Dis. 2002;6(2):125-8.

39. Sierra BD, García G, Pérez AB, Morier L, Álvarez M, Kourí $G$, et al. Ethnicity and Difference in Dengue Virus-Specific Memory $\mathrm{T}$ Cell Responses in Cuban Individuals. Viral Immunol. 2006;19(4):662-8.

40. de la CSB, Kourí G, Guzmán MG. Race: a risk factor for dengue hemorrhagic fever. Arch Virol. 2007;152(3):533-42.

41. Sierra B, Alegre R, Pérez AB, García G, SturnRamírez K, Obasanjo $O$, et al. HLA-A, -B, -C, and -DRB1 allele frequencies in Cuban individuals with antecedents of dengue 2 disease: Advantages of the Cuban population for HLA studies of dengue virus infection. Hum Immunol. 2007;68(6):531-40.

42. Pérez AB, Sierra B, García G, Aguirre E, Babel $\mathrm{N}$, Álvarez M, et al. Tumor necrosis factor-alpha transforming growth factor-1, and interleukin-1gene polymorphisms: implication in protection or susceptibility to dengue hemorrhagic fever. Human Immunol. 2010;71:1135-40.

43. García G, Sierra B, Morier L, Guzmán M, Álvarez $M$, Pérez AP, et al. IL-2 level in past dengue infection. Dengue Bull. 2001;25:65-8.

44. Sierra B, Pérez AB, Vogt K, García G, Schmolke K, Aguirre E, et al. Secondary heterologous dengue infection risk: disequilibrium between immune regulation and inflammation. Cellular Immunol. 2010;262:134-40.

45. García G, Puerto FD, Pérez AB, Sierra B, Aguirre $\mathrm{E}$, Kikuchi M, et al. Association of MICA and MICB alleles with symptomatic dengue infection. Human Immunol. 2011;72:904-7.

46. Guzmán MG, Deubel V, Pelegrino JL, Rosario D, Marrero M, Sariol C, et al. Partial nucleotide and amino acid sequences of the envelope and the envelope/nonstructural protein-1 gene junction of four dengue-2 virus strains isolated during the 1981 Cuban epidemic. Am J Trop Med Hyg. 1995;52(3):241-6.

47. Álvarez M, Guzmán MG, Rosario D, Vázquez S, Pelegrino JL, Sariol CA, et al. Direct sequencing of an amplified product from a serum sample. Rev Cubana Med Trop. 1996;48(1):53-5.

48. Sariol CA, Pelegrino JL, Martínez A, Arteaga E, Kourí G, Guzmán MG. Detection and genetic relationship of dengue virus sequences in seventeenyear-old paraffin-embedded samples from Cuba. Am J Trop Med Hyg. 1999;61(6):994-1000.

49. Rodríguez-Roche R, Álvarez M, Gritsun T, Halstead S, Kourí G, Gould EA, et al. Virus evolution during a severe dengue epidemic in Cuba, 1997. Virology. 2005;334(2):154-9.

50. Rodríguez-Roche $\mathrm{R}$, Álvarez $\mathrm{M}$, Gritsun $\mathrm{T}$, Rosario D, Halstead S, Kourí G, et al. Dengue virus type 2 in Cuba, 1997: conservation of $E$ gene sequence in isolates obtained at different times during the epidemic. Arch Virol. 2005;150(3):415-25.

51. Rodríguez-Roche $R$, Álvarez $M$, Holmes EC, Bernardo L, Halstead S, Kourí G, et al. Dengue virus type 3 in Cuba: Evolution from a Small Outbreak in 2000 to a Major Epidemic in 2001. Emerg Infect Dis. 2005;11(5);773-4.

52. Rodríguez-Roche R, Sánchez L, Burgher $\mathrm{Y}$, Rosario D, Álvarez M, Kourí $G$, et al. Virus role during intraepidemic increase in dengue disease severity. Vector Borne Zoonotic Dis. 2011;11(6):675-81.

53. Guzmán MG, Kourí G, Halstead SB. Do escape mutants explain rapid increases in dengue case-fatality rates within epidemics? Lancet. 2000;355(9218):1902-3.

54. Guzmán MG, Kourí G. Dengue haemorrhagic fever integral hypothesis: confirming observations, 1987-2007. Trans R Soc Trop Med Hyg 2008;102(6):522-3

55. Martínez E. Dengue y dengue hemorrágico. Editorial de la Universidad de Quilmes; 1998. p. 1-269.

56. Martínez Torres E. Preventing deaths from dengue: a space and challenge for primary health care. Rev Panam Salud Publica. 2006;20(1):60-74.

57. González D, Castro O, Pérez J, Martínez E, Vázquez S, Rosario $D$, et al. Classical dengue hemorrhagic fever resulting from two dengue infections spaced 20 years or more apart: Havana, Dengue 3 epidemic, 2001-2002. Int J Infect Dis. 2005;9:280-5.

58. González AL, Martínez RA, Villar LA. Clinical evolution of dengue in hospitalized patients. Biomedica. 2008;28(4):531-43.

59. González D, Limonta D, Bandera JF, Pérez J, Kourí G, Guzmán MG. Dual infection with dengue virus 3 and human immunodeficiency virus 1 in Havana, Cuba. J Infect Dev Ctries. 2009;3(4):318-20.

60. García GSB, Pérez AB, Aguirre E, Rosado I, González N, Izquierdo A, et al. Asymptomatic dengue infection in a Cuban Population confirms the protective role of the RR variant of the PcRlla polymorphism. American J Tropical Med Hygiene. 2010;82(6):1153-6.

61. García G, González N, Pérez AB, Sierra B, Aguirre $E$, Rizo D, et al. Long-term persistence of clinical symptoms in dengue-infected persons and its association with immunological disorders. Int J Infect Dis. 2011;15(1):e38-43.

62. Vázquez S, Ruiz D, Barrero R, Ramírez R, Calzada N, Peña BR, et al. Kinetic of dengue virus NS1 protein in dengue 4 confirmed adults patients. Diagn Microbiol Infect Dis. 2010;68:46-9.

63. Vázquez $S$, Acosta $N$, Ruiz $D$, Calzada $N$, Álvarez AM, Guzmán MG. Immunoglobulin G antibody response in children and adults with acute dengue 3 infection. J Virol Methods. 2009;159(1):6-9.

64. Vázquez S, Valdivia I, Sánchez A, Calzada N, Guzmán MG. Evaluación del sistema diagnóstico UMELISA DENGUE IgM PLUS. Archivos Venezolanos de Medicina Tropical. 2007;5:4-20.

65. Vázquez S, Cabezas S, Pérez AB, Pupo M, Ruiz $D$, Calzada N, et al. Kinetics of antibodies in sera, saliva, and urine samples from adult patients with primary or secondary dengue 3 virus infections. Int J Infect Dis. 2007;11:256-62

66. Vázquez $S$, Pérez $A B$, Ruiz $D$, Rodríguez $R$, Pupo M, Calzada N, et al. Serological markers during Dengue 3 primary and secondary infections. J Clin Virol. 2005;33(2):132-7.

67. Vázquez S, Valdés O, Pupo M, Delgado I, Álvarez M, Pelegrino JL, et al. MAC-ELISA and ELISA inhibition methods for detection of antibodies after yellow fever vaccination. J Virol Methods. 2003;110(2):179-84.
68. Vázquez S, Saenz E, Huelva G, González A, Kourí G, Guzmán M. Detección de IgM contra el virus del dengue en sangre entera absorbida en papel de filtro. Rev Panam Salud Publica. 1998;3(3):174-8.

69. Rosario D, Álvarez M, Díaz J, Contreras R, Rodríguez R, Vázquez $S$, et al. Reacción en cadena de la polimerasa para la detección rápida y determinación del serotipo de virus del dengue en muestras clínicas. Rev Panam Salud Pública. 1998;4(1):1-5.

70. Rosario Domínguez D, Suárez Moran CM, Rodríguez Roche R, Soler Nodarse M, Guzmán Tirado MG. Identificación rápida de los serotipos del virus del dengue mediante la reacción en cadena de la polimerasa. Rev Cubana Med Trop. 1996;48(3):155-60.

71. Pelegrino JL, Arteaga E, Rodríguez AJ, González E, Frontela MD, Guzmán MG. Normalizacióon de técnicas inmunohistoquímicas para la detección de antígenos del virus dengue en tejidos embebidos en parafina. Rev Cubana Med Trop. 1997;49(2):100-7.

72. Pelegrino JL, Vázquez S, Guzmán MG, Valdivia A, Rogés G. Rapid diagnosis of dengue virus using a novel enzyme-immunosorbent assay (ELISA) kit. In: Tenth Annual Clinical Virology Symposium and Annual Meeting Pan American Group for Rapid Diagnosis: USA;1994. p. 74.

73. Rodríguez-Roche R, Álvarez M, Guzmán MG, Morier L, Kourí G. Comparison of rapid centrifugation assay with conventional tissue culture method for isolation of dengue 2 virus in C6/36HT cells. J Clin Microbiol. 2000;38(9):3508-10.

74. Pupo-Antunez M, Rodríguez R, Álvarez M, Amin $\mathrm{N}$, Rodríguez $\mathrm{H}$, Otero $\mathrm{A}$, et al. Development of a monoclonal antibody specific to a recombinant envelope protein from dengue virus type 4 expressed in Pichia pastoris. Hybridoma. 2001;20(1):35-41.

75. Pupo Antunez M, Álvarez Vera M, Soto Hernández M, Rodríguez Sánchez H, Rodríguez Díaz R, Morier Diaz L, et al. Anticuerpos monoclonales al virus dengue 4: espectro de reactividad a los 4 serotipos del dengue. Monoclonal antibodies to dengue virus 4: the spectrum of the reactivity to 4 serotypes of dengue. Rev Cubana Med Trop. 2000;52(2):119-25.

76. Pupo-Antunez $M$, Rodríguez $H$, Vázquez $S$, Vilaseca JC, Álvarez M, Otero A, et al. Monoclonal antibodies raised to the dengue-2 virus (Cuban: A15 strain) which recognize viral structural proteins. Hybridoma. 1997;16(4):347-53.

77. Álvarez AM. Sistema integrado de vigilancia para la prevención del dengue. Municipio Cotorro, La Habana, Cuba. Rev Cubana Med Trop. 2007;59(3):193-201.

78. Díaz CTY, De la Cruz AM, Álvarez AM, Piquero ME, Valero A, Fuentes O. Estrategia intersectorial y participativa con enfoque de ecosalud para la prevención de la transmisión de dengue en el nivel local. Cadernos de Saúde Pública Rio de Janeiro. 2009;25(supl.1):59-70. ISSN 0102311X.

79. Pérez D, Lefevre P, Sánchez L, Van der Stuyft P. Comment on: What do community-based dengue control programmes achieve? A systematic review of published evaluations. Trans $\mathrm{R}$ Soc Trop Med Hyg. 2007;101:630-1.

80. Toledo ME, Vanlerberghe V, Baly A, Ceballos $E$, Valdés $L$, Searret $M$, et al. Towards active community participation in dengue vector control: results from action research in Santiago de Cuba, Cuba. Trans R Soc Trop Med Hyg. 2006;101:56-63.

81. Toledo Romani ME VV, Pérez D. Achieving sustainability of community-based dengue control in Santiago de Cuba. Social Science Med. 2007;64:976-88. 
82. Toledo ME, Rodríguez A, Valdés L, Carrion R, Cabrera G, Banderas D, et al. Evidence on impact of community-based environmental management on dengue transmission in Santiago de Cuba. Trop Med Int Health. 2011;16(6):744-7.

83. Bisset Lazcano JA, Marquetti MC, González B, Mendizabal ME, Navarro A. Abundance of larvae of urban mosquitoes during the campaign of the eradication of Aedes aegypti (Linnaeus, 1762) and of dengue in Cuba (1981-82). Rev Cubana Med Trop. 1985;37(2):161-8.

84. Bisset JA, San Martín JL, Romero JE, Montoya $\mathrm{R}$. Evaluación de la resistencia a insecticidas de una cepa de Aedes aegypti de El Salvador. Rev Panam Salud Pública. 2009;26(3):229-34

85. Marquetti MC, Bisset JA, García A. Recipientes asociados a la infestación por Aedes aegypti en La Lisa, Ciudad de La Habana, Cuba. Rev Cubana Med Trop. 2009;61(3):232-8.

86. Rodríguez MM, Bisset JA, Pérez O, Montada D, Moya M, Ricardo Y, Valdéz V. Estado de la resistencia a insecticidas y sus mecanismos en Aedes aegypti en el municipio Boyeros. Rev Cubana Med Trop. 2009;61(2):170-6.

87. Rodríguez MM, Ricardo $Y$, Pérez $\mathrm{O}$, Montada D, Figueredo D, Fuentes I. Resistencia a insecticidas organofosforados en Aedes aegypt (Diptera: Culicidae) de Santiago de Cuba en el período 1997-2009. Rev Cubana Med Trop. 2010;62(3):217-23.

88. Bisset JA, Rodríguez MM, Ricardo $\mathrm{Y}$, Ranson $\mathrm{H}$ Pérez O, Moya M, et al. Temephos resistance and esterase activity in the mosquito Aedes aegypti in Havana, Cuba increased dramatically between 2006 and 2008. Medical and Veterinary Entomology. 2011;25(3):233-9.

89. Fuentes O, López R, Marquetti MC, Lugo J Presence of Aedes (Gymnometopa) mediovittatus in Cuba: a new factor to be considered in the national campaign to eradicate dengue. Bull Pan Am Health Organ. 1992;26(1):14-7.

90. Guzmán MG, Triana C, Bravo J, Kourí G. The estimation of the economic damages caused as a consequence of the epidemic of hemorrhagic dengue in Cuba in 1981. Rev Cubana Med Trop. 1992;44(1):13-7.

91. Valdés L, Vila J, Guzmán MG. Impacto económico de la epidemia de dengue 2 de Santiago de Cuba, 1997. Rev Cubana Med Trop. 2002;54(3):220-7

92. Baly O, Vanlerberghe V, Ceballos E, Reyes A, Sánchez I, Carvajal M, et al. Effectiveness of Community-Based Approach Intertwined with a Vertical Aedes Control Program. Am J Trop Med Hyg. 2009;81(1):88-93

93. Baly A, Flessa S, Cote M, Thiramanus T, Vanlerberghe $\mathrm{V}$, Villegas $\mathrm{E}$, et al. The cost of routine Aedes aegypti control and of insecticide-treated curtain implementation. Am J Trop Med Hyg. 2011;84(5):747-52.

94. Álvarez M, Guzmán MG, Pupo M, Morier L, Bravo J, Rodríguez R. Study of biologic attributes of Cuban dengue 2 virus after serial passage in primary dog kidney cells. Int $\mathrm{J}$ Infect Dis. 2001;5(1):35-9.

95. Mune M, Rodríguez R, Ramírez R, Soto Y, Sierra $B$, Rodríguez Roche $R$, et al. Carboxy-terminally truncated Dengue 4 virus envelope glycoprotein expressed in Pichia pastoris induced neutralizing antibodies and resistance to Dengue 4 virus challenge in mice. Arch Virol. 2003;148(11):2267-73.

96. Sierra Vázquez B, Pérez Díaz AB, Vázquez Villasuso V, Rodríguez Díaz R, García Menéndez G Guzmán Tirado MG. Assessment of the cellula immune response induced in Balb/C mice with dengue virus 2 envelope protein. Rev Cubana Med Trop. 1999:51(2):95-8.

97. Guzmán MG, Rodríguez R, Hermida L, Álvarez M, Lazo L, Mune M, et al. Induction of neutral- izing antibodies and partial protection from viral challenge in Macaca fascicularis immunized with recombinant dengue 4 virus envelope glycopro tein expressed in Pichia pastoris. Am J Trop Med Hyg. 2003;69(2):129-34.

98. Guillen G, Aguilar JC, Duenas S, Hermida L, Guzmán MG, Penton E, et al. Virus-like particles as vaccine antigens and adjuvants: application to chronic disease, cancer immunotherapy and infectious disease preventive strategies. Procedia Vaccinology. 2010;2:128-33.

99. Guzmán MG, Hermida L, Bernardo L, Ramírez $\mathrm{R}$, Guillen $\mathrm{G}$. Domain III of the envelope protein as a dengue vaccine target. Expert Rev Vaccines. 2010;9(9):87-97.

100. Guzmán MG. Dengue vaccines: new developments. Drugs Future. 2011;36(1):45-62.

101. Hermida L, Rodríguez R, Lazo L, López C, Márquez G, Paez R, et al. A recombinant envelope protein from Dengue virus purified by IMAC is bioequivalent with its immune-affinity chromatography purified counterpart. J Biotechnol. 2002;94(2):213-6.

102. Hermida L, Rodríguez R, Lazo L, Bernardo L, Silva R, Zulueta A, et al. A fragment of the Envelope protein from Dengue-1 virus, fused in two different sites of the meningococcal P64k protein carrier, induces a functional immune response in mice. Biotechnol Appl Biochem. 2003;39:107-14.

103. Hermida L, Rodríguez R, Lazo L, Silva R, Zulueta A, Chinea $G$, et al. A dengue-2 Envelope fragment inserted within the structure of the P64k meningococcal protein carrier enables a functional immune response against the virus in mice. J Virol Methods. 2004;115(1):41-9.

104. Hermida L, Bernardo L, Martín J, Álvarez M, Prado I, López C, et al. A recombinant fusion protein containing the domain III of the dengue-2 envelope protein is immunogenic and protective in nonhuman primates. Vaccine. 2006;24(16):3165-71.

105. Izquierdo A, Bernardo L, Martín J, Santana E, Hermida L, Guillen G, et al. Serotype-specificity of recombinant fusion proteins containing Domain III of dengue virus. Virus Res. 2008;138(1-2):135-8

106. Valdés I, Hermida L, Zulueta A, Martín J, Silva $\mathrm{R}$, Álvarez $\mathrm{M}$, et al. Expression in Pichia pastoris and immunological evaluation of a truncated Dengue envelope protein. Mol Biotechnol. 2007;35(1):23-30.

107. Valdés I, Hermida L, Martín J, Menéndez T, Gil L, Lazo L, et al. Immunological evaluation in nonhuman primates of formulations based on the chimeric protein P64k-domain III of Dengue 2 and two components of Neisseria meningitidis. Vaccine. 2009;27:995-1001.

108. Valdés I, Bernardo L, Gil L, Pavón A, Lazo L, López $\mathrm{C}$, et al. A novel fusion protein domain III-capsid from dengue-2, in a highly aggregated form, induces a functional immune response and protection in mice. Virology. 2009;394(2):249 58.

109. Valdés I, Hermida L, Gil L, Lazo L, Castro J, Martín J, et al. Heterologous prime-boost strategy in non-human primates combining the infective dengue virus and a recombinant protein in a formulation suitable for human use. Int J Infect Dis. 2009;14(5):e377-83.

110. Valdés I, Gil L, Romero Y, Castro J, Puente P, Lazo $\mathrm{L}$, et al. The chimeric protein domain IIIcapsid of dengue virus serotype 2 (DEN-2) successfully boosts neutralizing antibodies generated in monkeys upon infection with DEN-2 Clin Vaccine Immunol. 2011;18(3):455-9.

111. Lazo L, Hermida L, Zulueta A, Sanchez J, Lopez C, Silva R, et al. A recombinant capsid protein from Dengue-2 induces protection in mice against homologous virus. Vaccine. 2007;25(6):1064-70.

112. Lazo L, Zulueta A, Hermida L, Blanco A, Sánchez J, Valdés I, et al. The Dengue-4 envelope domain III fused twice within the meningococcal P64k protein carrier induces partial protection in mice. Biotechnology Applied Biochemistry. 2008.52:265-7.

113. Lazo L, Zulueta A, Hermida L, Blanco A, Sanchez J, Valdés I, et al. Dengue-4 envelope domain III fused twice within the meningococcal P64k protein carrier induces partial protection in mice. Biotechnol Appl Biochem. 2009;52(Pt 4):265-71.

114. Lazo L, Gil L, López C, Valdés I, Marcos E, Álvarez M, et al. Nucleocapsid-like particles of dengue-2 virus enhance the immune response against a recombinant protein of dengue- 4 virus. Arch Virol. 2010;155(10):1587-95

115. Bernardo L, Yndart A, Vázquez S, Morier L, Guzmán MG. Antibody responses to Asian and American genotypes of dengue 2 virus in immunized mice. Clin Diagn Lab Immunol. 2005;12(2):361-2

116. Bernardo L, Izquierdo A, Prado I, Rosario D, Álvarez M, Santana E, et al. Primary and Secondary Infections by Asian and American Genotypes of Dengue 2 Virus in Macaca Fascicularis Monkeys. Clin Vaccine Immunol. 2007; 15(3):439-46.

117. Bernardo L, Hermida L, Martín J, Álvarez M, Prado I, Lopez C, et al. Anamnestic antibody response after viral challenge in monkeys immunized with dengue 2 recombinant fusion proteins. Arch Virol. 2008;153(5):849-54

118. Bernardo L, Izquierdo A, Álvarez M, Rosario D, Prado I, López C, et al. Immunogenicity and protective efficacy of a recombinant fusion protein containing the domain III of the dengue 1 envelope protein in nonhuman primates. Antiviral Research. 2008:80:194-9.

119. Bernardo L, Izquierdo A, Prado I, Rosario D Álvarez M, Santana E, et al. Primary and Secondary Infections by Asian and American Genotypes of Dengue 2 Virus in Macaca Fascicularis Monkeys. Clin Vaccine Immunol. 2008;15(3):439-46.

120. Bernardo L, Fleitas O, Pavon A, Hermida L, Guillen G, Guzmán MG. Antibodies induced by dengue virus type 1 and 2 envelope domain III recombinant proteins in monkeys neutralize strains with different genotypes. Clin Vaccine Immunol. 2009;16(12):1829-31.

121. Bernardo L, Pavon A, Hermida L, Gil L, Valdés I, Cabezas S, et al. The two component adjuvant IC31(R) potentiates the protective immunity induced by a dengue 2 recombinant fusion protein in mice. Vaccine. 2011;29(25):4256-63.

\section{THE AUTHOR}

María G. Guzmán Tirado, distinguished researcher and full professor, Pedro Kourí Tropical Medicine Institute, PAHO/WHO Collaborating Center for the Study and Control of Dengue, Havana, Cuba. 